\title{
POTENTIAL OF INTEGRATION OF NATURAL RESOURCES INTO THE MARKET INFLUENCE ZONE
}

\section{Petro Korenyuk ${ }^{1}$, Anatolii Sunduk ${ }^{2}$, Liudmila Levkovska ${ }^{3}$, Liudmila Koreniuk ${ }^{4}$, Antonina Zienina-Bilichenko ${ }^{5}$}

${ }^{I}$ D.Sc., Professor, Dniprovsk State Technical University, Kamianske 51918, Ukraine

${ }^{2}$ D.Sc., Professor, Public Institute "Institute of Environmental Economics and Sustainable Development of NAS of Ukraine”, Kyiv 01032, Ukraine

${ }^{3}$ D.Sc., Professor, Public Institute "Institute of Environmental Economics and Sustainable Development of NAS of Ukraine”, Kyiv 01032, Ukraine

${ }^{4}$ PhD (Econ), Dnipropetrovsk National University named after V. Lazaryan, Dnipro 49010, Ukraine

${ }^{5}$ PhD (Econ), National University of Food Technologies, Kyiv 01033, Ukraine

Received 1508 2021; Accepted 20092021

\begin{abstract}
The article examines the problems of integration of natural resources into the zone of market influence. The analysis of researches on these questions is carried out, the problem moments are allocated. An algorithm for integrating natural resources into the market environment has been developed, which provides for the natural resource to go through stages with a change in their positions and the formation of market asset features. Possibilities of incorporation of land resources into the market, the potential of business development, and formation of the market of natural resource assets are investigated. The parameters of capitalization of natural resources and the concentration ratio of financial and economic regulation are calculated. Ways to strengthen the potential for integration of natural resources into the market area of influence have been developed. The study showed that to incorporate a natural resource into the area of market influence, it needs to go through several stages, and each of them is characterized by changes in the properties of resources, their gradual interaction with market participants. Even though there is a rather low level of capitalization of natural resources (in particular for land $-12.0 \%$, water $-10.8 \%$ ), the coefficient of concentration of activity can identify some regions with good opportunities for incorporation. The regions of Ukraine are grouped by the coefficient of concentration of land use activity and four groups of regions with coefficients are calculated: the highest priority by the activity of regulation, high level of concentration, medium and low.
\end{abstract}

Keywords: natural resources, integration, market, algorithm, incorporation, capitalization, regulatory activity. JEL Classification: M10,J24, L26 Q32, O47.

\section{Introduction}

In modern conditions, the global landscape is formed by processes that are localized within different poles of influence and pursue opposing interests. The global trend is the spread and formation of postindustrial formations, trends in the information economy, its integration into the vast majority of areas of development. The strengthening of the positions of financial markets and the growing role of powerful TNCs that can compete with states have a significant impact. In particular, Amazon, Microsoft, and Alphabet / Google are similar.

Copyright (C) 2021 Author(s), published by Vytautas Magnus University. This is an open access article distributed under the terms of the Creative Commons Attribution Non-Commercial 4.0 (CC BY-NC 4.0) license, which permits unrestricted use, distribution, and reproduction in any medium provided the original author and source are credited. The material cannot be used for commercial purposes. 
Examples of collaboration between quite different types of activities that find common areas of interaction are relevant and innovative. Under its influence, new types of economic activity are formed, existing ones are changed. These processes, given their potential and rapid spread, also apply to natural resources, which to some extent have been sidelined and have shown no interest in maintaining current trends. However, it should be noted that modern approaches and technologies provide the basis for such interactions and it is already possible to identify several successful cases. Similar is the possibility of interaction between natural resources and the market.

The experience of foreign countries (in particular, the G7) convincingly proves that such interactions are already becoming a reality and have favorable effects. However, research is ongoing, and some important issues need to be addressed. The list of relevant issues includes research on the features and ways of natural resources integration into the market area, the formation of theoretical and methodological foundations of these processes, the establishment of their digital indicators, ways to strengthen the integration of natural resources into the market area.

\section{Literatute review}

Given the relevance of such studies, it is now possible to single out a list of works on individual issues of interaction between natural resources and the market. Note that a number of them explore the processes and tools for economizing natural resources. An important element in this regard is the cost of natural resources, which is studied in the monograph (Pyrozhkov, Khvesyk, 2015). Note that this work contains many innovative elements (in particular, the inclusion in the cost items of payments for ecosystem services). An important monograph on the study of the natural resource potential of Ukraine (Rudenko, 1993).

In the use of natural resources, a necessary aspect is the use of various levers of regulation, which will ensure their systematic use. Similar issues are explored in the development of "Financial and economic principles of nature management" with an assessment of the basic characteristics of the use of regulatory means (Burkynskyi et al., 2018; Kostetska, Smol, Gaska, 2018; Khvesyk, 2020). The research of Prokopenko, Shkola (2012), Pimonenko, Prokopenko, Dado (2017) are devoted to the problem of natural resource potential management in new conditions. In this sense, it is important to introduce the integrated management of natural resources (Global Water Partnership, 2005; 2012).

Some works on research of separate elements (stages) of integration of natural resources into a zone of influence of the market are important. In particular, similar are the articles by Hvesyk, Bystryakova and Klinovy (2018) (a separate issue, that examines the problem of the formation of natural resource assets). Malyuga, Zamula (2001) researched the problematic issues of natural capital.

Given the relevance of these issues, the objectives of the study are to develop theoretical and applied foundations for the integration of natural resources and the market, highlighting the features of this process. Besides, it is important to establish digital features of the process that can reveal the peculiarities of interactions.

\section{Methodology}

In article are formed theoretical and practical foundations for the integration of natural resources and the market with a researching of the peculiarities of this process and to determine the possibility of incorporation of land resources into the market area of influence.

The methodological basis of the study is formed by the key provisions, principles, and methods of modern economic theory, as well as the conceptual approaches of schools of economics to study the problems of development of interactions between natural resources and the market. The following methods were used in the study: statistical in order to assess the quantitative characteristics of the functioning of state 


\title{
S sciendo
}

\author{
Management Theory and Studies for Rural Business and Infrastructure Development \\ eISSN 2345-0355. 2021. Vol. 43. No. 3: 430-441 \\ Article DOI: https://doi.org/10.15544/mts.2021.39
}

systems; system-structural - to determine the nature, structure, and basic approaches to the management of the national economy and others. It is important to use economic methods in order to establish the quantitative features of the process of interactions.

In particular, the method of calculating the concentration coefficient of financial and economic regulation activity was used to establish the peculiarities of regulation. For this purpose, it is advisable to use the procedure of standardization of indicators during a particular year (Stepanenko, Herasymov, 2002). It is possible to allocate stages of research: standardization of the indicators characterizing features of regulation; calculation of integral quantities for the regions of the state; calculation of coefficients of concentration of activity of regions of Ukraine as a whole. The calculation of integral quantities is carried out according to formula 1 :

$$
\mathrm{Z}_{\mathrm{i}}^{*}=\frac{\mathrm{Z}_{i 1}+\mathrm{Z}_{i 2}+\ldots .+\mathrm{Z}_{\mathrm{ij}}+\ldots . \mathrm{Z}}{n}, i=1 \ldots . m
$$

where $\mathrm{Z}_{\mathrm{i}}^{*}$ - integrated assessment of regional indicators;

$Z_{i 1}, Z_{i 2}, Z_{i j}, Z$ - standardized indicators of regions;

$\mathrm{n}$ - the number of incomparable indicators;

$i$ - comparable value;

$\mathrm{m}$ - the number of regions $(i=1 \ldots m)$.

The activity concentration coefficient $Y_{i}$ for any region can be calculated based on formula 2:

$$
Y_{i}=\frac{Z^{*}{ }_{i}}{Z^{*}{ }_{0}} i=1 \ldots m
$$

where $Y_{i}-\mathrm{K}_{\text {ка }}$ financial and economic regulation of the region;

$\mathrm{Z}_{\mathrm{i}}^{*}$ - ntegrated assessment of regional indicators;

$\mathrm{Z}_{0}{ }^{*}$ - integrated assessment of the upper pole of the state;

$m-$ the number of regions $(i=1 \ldots m)$.
Besides, to calculate the level of capitalization, the method of the ratio of the average return on resource use to its value is used. Average profitability correlates with rental indicators (in terms of closing costs). If the capitalization is less than $15 \%$, the resource is undercapitalized (Khvesyk, 2020).

\section{Results}

Natural resource (NR) provided its integration into the sphere of influence of the market, changes its individual properties, and gradually implements new market positions. It is clear that to pass these stages, significant motivational principles and economic preferences are needed, which can be used under the condition of such integration. In other words, interests that may be drivers for the development of such interactions are necessary.

Explore the separate interests of a natural resource and market conditions for their convergence. It is logical to assume that the interests may differ for these entities, but it is possible to single out a block of common. Studies show that the main interests of natural resources include: the possibility of shifting the emphasis of use to market positions (from 0.4 to 0.75 points, which will contribute to their economic operation); disclosure of economization potential; with the help of market tools - strengthening their greening; improving the properties of natural resources.

Market interests are more closely linked to money and provide new opportunities to attract untapped assets to economic activity; inclusion of cost characteristics of natural resources in market processes; expansion of the field of investment (currently in the agricultural sector continues to implement more than 400 investment projects (Ministry of Agriculture of Ukraine, 2020); the possibility of forming balanced business projects with the participation of natural resources; the possibility of introducing new instruments (payments for ecosystem services, which at world prices can be several 
times higher than rent payments to local budgets) (Fig. 1).

Subject to the actualization of the system of interests of the manifestation of interactions, it is possible to form the stages of integration of the natural resource into the zone of market influence, which involves several steps. The first is a gradual change in the position of natural resources.

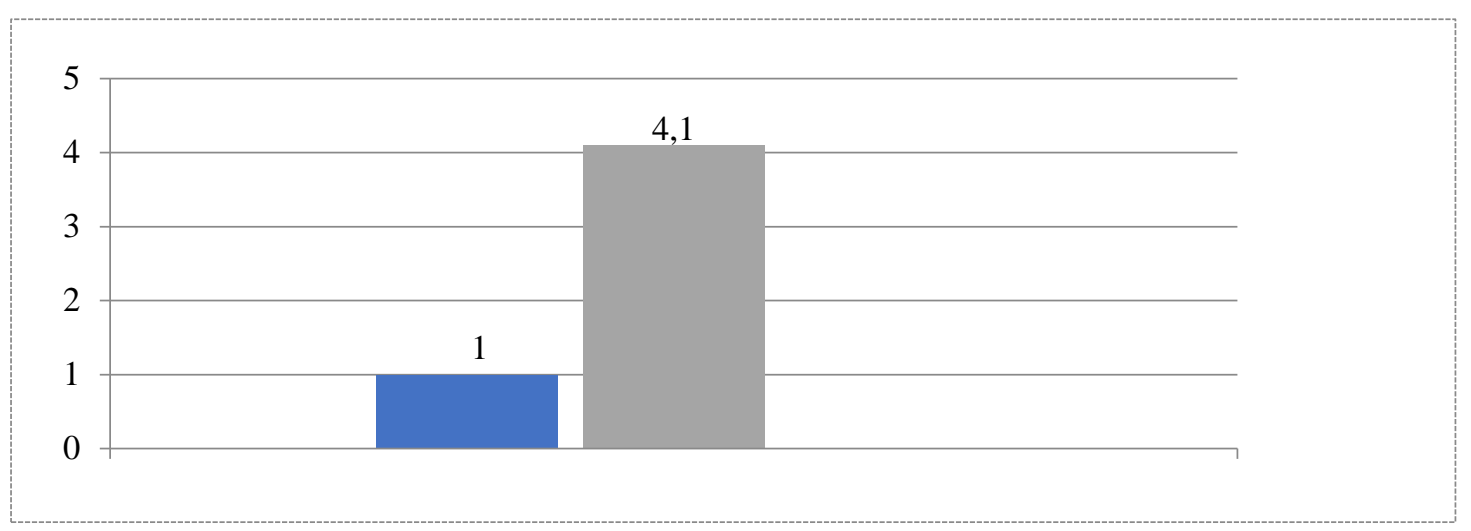

Figure 1. Opportunities for growth of payments for ecosystem services for pastures and arable land, times, 2018 year ( 1 - basic level; 2 - promising)

Under these conditions, the natural resource, using a system of tools, can be gradually integrated (incorporated) into the area of market influence (Fig. 2). An important prerequisite for this stage is high rates of capitalization and activity of financial and economic regulation.

With the penetration of natural resources in the zone of influence of the market first important step in a business activity other algorithm stages as follows: market development of natural resource assets $\rightarrow$ PR positioning as an asset market economy $\rightarrow$ distribution platform markets. Note that the passage of these stages is a natural resource to expand their functional properties by reducing commodity positions and gradually updating the market. For land resources, raw materials include the satisfaction of consumer needs in agricultural products, land as a space for the activities of agricultural industries, and others. This approach has largely led to excessive pressure on natural resources and environmental issues. 


\section{Sciendo}

Management Theory and Studies for Rural Business and Infrastructure Development

eISSN 2345-0355. 2021. Vol. 43. No. 3: 430-441

Article DOI: https://doi.org/10.15544/mts.2021.39

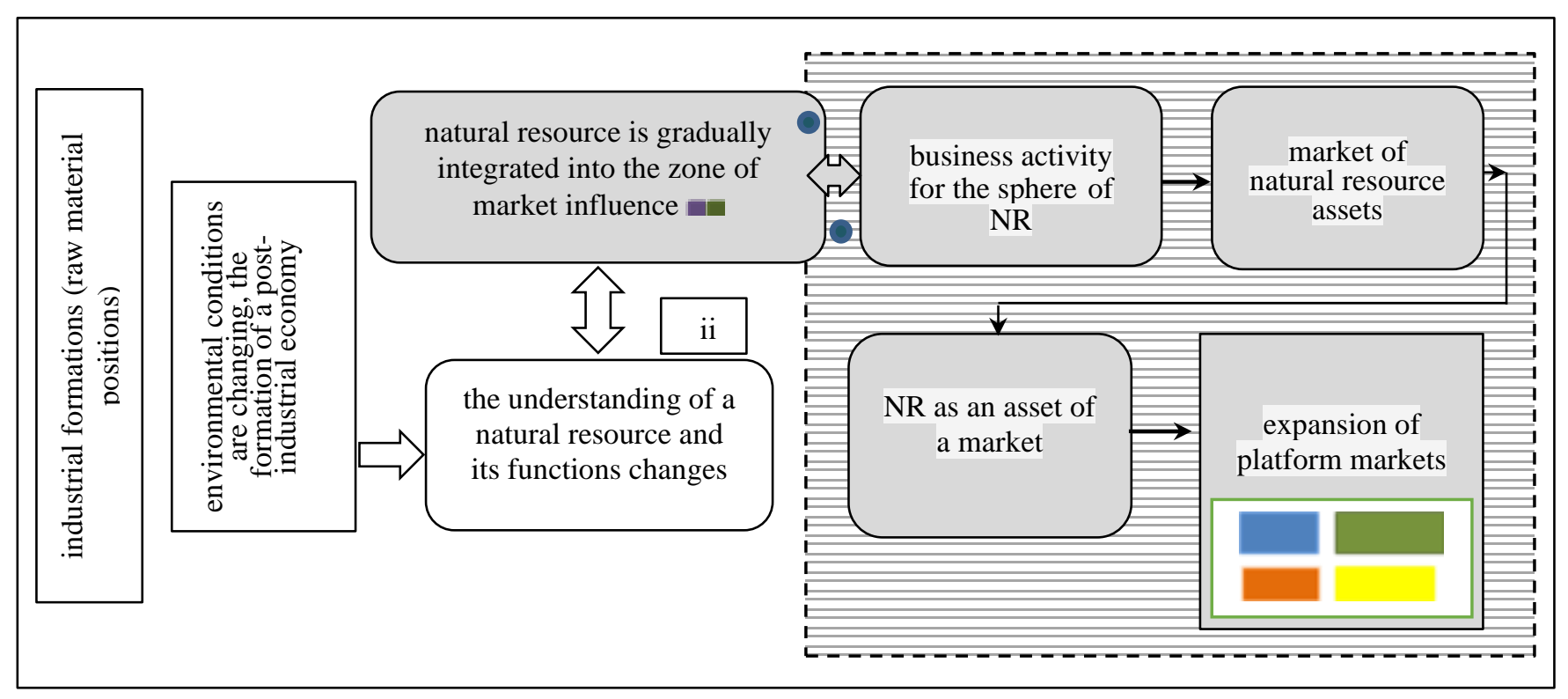

Figure 2. Stages of integration of natural resources into the zone of market influence

(ii - integration tools; - system effects; - capitalization; - the activity of financial and economic regulation; - - - - a sphere of market influence; 原 - cash flows)

Market positions can be specified by strengthening the cost characteristics; building cooperation with the business sector (the possibility of entering the sphere of influence of private companies); formation of financial flows; using new regulatory tools (payments for ecosystem services). In general, research shows that land resources can strengthen and implement market positions and are a valuable asset that can be effectively integrated into market processes and generate cash flows. After the change (expansion of functional positions), the natural resource is gradually integrated (incorporated) into the zone of the market influence. And this stage ensures the direct inclusion of natural resources in market processes.

The incorporation processes for the current stage of development in Ukraine are quite problematic, due to the influence of several processes. There are reasons, as the low level of economic development, the functioning of the institutional environment, the lack of tools, and the low level of state support. This is confirmed by the low global ratings of the state. According to the rating of ease of doing business (Doing Business,
2020), Ukraine in 2020 took 64th place, according to the study of the level of innovation processes (Global Innovation Indexб 2020), the state took 45th position. But, at the same time, there is a strong request from the business to carry out these procedures. Also, the positive foreign experience shows that the incorporation processes are promising and the states have already passed and resolved these issues. Note that such incorporation processes are possible under conditions of high activity for the industry, which can be specified by the capitalization ratio and the concentration ratio of financial and economic regulation (Tamosiuniene, Demianchuk, Koval, 2019).

An important prerequisite for the development of such interactions is the concept of capitalization. This concept ensures the "marketability" of the natural resource and its similarity to the assets of a market economy. It is important for their interaction. In general, if the capitalization is less than $15 \%$, the resource is considered undercapitalized. The level of assets capitalization in Ukraine in 2017 was $14.5 \%$, and in 2018 it increased slightly. Given the 
low parameters of current capitalization in the country, it is possible to predict that for the sphere of natural resources its level will be even lower, due to the fact that this sphere is not localized and does not gravitate to the market such as banking or the stock market. This is confirmed by the authors' calculations, according to which the real capitalization of natural resources is low. The potential capitalization is higher and is in 2018: for land resources $-12.0 \%$, water -10.8 , forest $2.9 \%$ (Fig. 3). But these figures do not correlate with the threshold level, although during 2017-2018 the capitalization increased for water and forest resources.

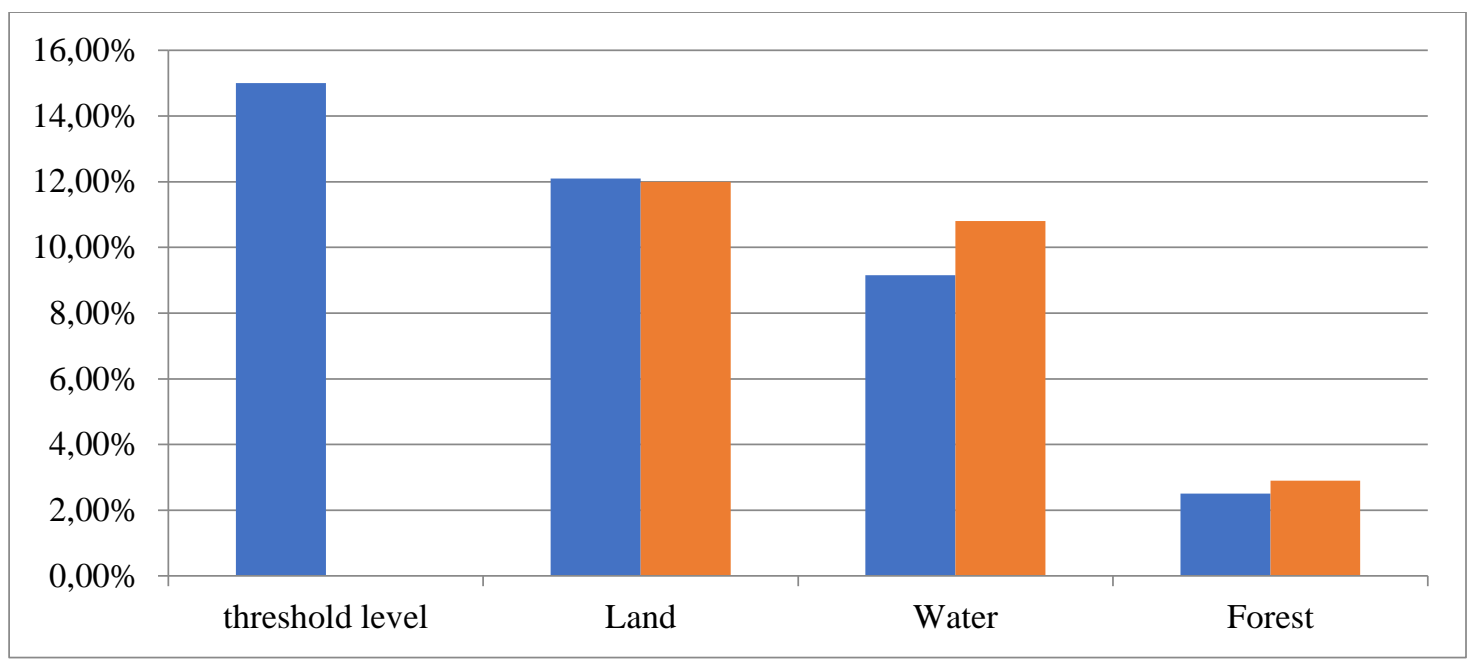

Figure 3. Potential level of capitalization of natural resources of Ukraine for the period 20172018, \%

In the regional aspect, the capitalization of natural resources varies. But, in the general trend, each indicator of the regions forms the national level. For water resources in 2018, high $\%$ of capitalization tend to Dnipropetrovsk and Donetsk regions. Besides, the Zaporizhia region also has a high level of capitalization. \% of these regions are $>10 \%$ and exceed the national level. The Cherkasy region also shows a high level. For land resources for the same year, the state indicator exceeds 11 regions. The maximum interest rates gravitate to the capital and industrial areas. Assessment of spatial features shows that individual regions may exceed the state level and the capitalization threshold.

In addition to capitalization, the second important indicator is the coefficient of activity concentration, which is formed by taking into account the following components: cost characteristics (estimated value based on regulatory monetary valuation), $\mathrm{UAH}$ million $\left(n_{1}\right)$; land tax (legal entity + individuals), UAH million (local budgets) $\left(n_{2}\right)$; rent (legal entity + individuals), UAH million (local budgets) $\left(n_{3}\right)$; proceeds from the sale of land, UAH million (local budgets) $\left(n_{4}\right) ;$ mastered (used) capital investments (land), UAH million $\left(n_{5}\right)$; mastered (used) capital investments in assets, UAH million $\left(n_{6}\right)$; agro-industrial complex products by regions, UAH million $\left(n_{7}\right)$. According to the methodology, the calculation involves several stages. After the formation of the source tables, the places of the regions for each indicator among other regions of the state are investigated. The maximum value (1.0) is inherent in the state. It is already clear that some indicators occupy more important positions. In particular, for $n_{1}$ (cost characteristics) high values are characteristic of the Donetsk region (0.0769) and Dnipropetrovsk (0.0758). 
An important step is the standardization (rationing) of indicators to bring their quantitative parameters to a single statistical base, which is associated with the number of regions (Table 1).

An important characteristic for the calculations is the upper pole - the maximum value of a particular indicator among all regions. The pole plays a major role in calculating the activity concentration factor. Among all areas, the maximum values of the upper pole tend to $n_{5}$ and $n_{2}$. These are mainly regions with strong land potential and appropriate monetary parameters (Table 1).

Table 1. Stage of standartization (rationing) of indicators of financial and economic regulation (fragment)

\begin{tabular}{|c|c|c|c|c|c|c|c|}
\hline & $\mathbf{n}_{1}$ & $\mathbf{n}_{2}$ & $\mathbf{n}_{3}$ & $\mathbf{n}_{4}$ & $\mathbf{n}_{5}$ & $\mathbf{n}_{6}$ & $\mathbf{n}_{7}$ \\
\hline Ukraine & 25 & 25 & 25 & 25 & 25 & 25 & 25 \\
\hline Vinnytsia region & 1.0096 & 0.6302 & 0.8508 & 1.6338 & 0.8373 & 1.8195 & 2.1033 \\
\hline Volyn region & 0.4728 & 0.4142 & 0.2731 & 0.7430 & 0.4082 & 0.5482 & 0.6073 \\
\hline Dnipropetrovsk & 1.8951 & 3.2449 & 3.5015 & 0.3845 & 2.5643 & 1.2134 & 1.4371 \\
\hline Donetskregion & 1.9219 & 0.8741 & 0.8038 & 0.5690 & 0.1181 & 0.4563 & 0.6241 \\
\hline Zhytomyr region & 0.8582 & 0.3842 & 0.4918 & 0.7151 & 0.5383 & 0.8710 & 1.0090 \\
\hline Transcarpatian region & 0.6360 & 0.3552 & 0.1907 & 2.2776 & 0.8029 & 0.0779 & 0.3268 \\
\hline Zaporizhia region & 0.7705 & 1.2954 & 1.3909 & 0.5011 & 0.7267 & 0.7984 & 0.7797 \\
\hline Ivano-Frankivsk & 0.6260 & 0.4086 & 0.5165 & 1.0040 & 0.6370 & 0.4218 & 0.5093 \\
\hline Kyiv region & 1.6587 & 1.2522 & 1.0397 & 2.2046 & 4.0296 & 2.5743 & 1.7080 \\
\hline Kirovograd & 0.4465 & 0.4709 & 0.7847 & 0.1322 & 0.0912 & 1.2564 & 1.2443 \\
\hline$\ldots \ldots$ & $\ldots$ & $\cdots \cdots$ & $\cdots \cdots$ & $\ldots$ & $\ldots$ & $\ldots$ & $\ldots$ \\
\hline The upper pole & 1.9219 & 5.7817 & 4.1016 & 4.3047 & 7.2623 & 2.5743 & 2.1033 \\
\hline
\end{tabular}

An important characteristic for the calculations is the upper pole - the maximum value of a particular indicator among all regions. The pole plays a major role in calculating the activity concentration factor. Among all areas, the maximum values of the upper pole tend to $n_{5}$ and $n_{2}$. These are mainly regions with strong land potential and appropriate monetary parameters.

The calculation of integrated quantities for the regions of the state is after rationing, which is carried out according to formula1. Integral values for the regions of Ukraine are rather uneven, which is due to the influence of objective processes. In particular, the maximum levels are typical for certain regions of central and southern Ukraine. These levels have a significant impact on the formation of the activity concentration ratio. The size of the capital is expressive, due to its position on a national scale. The formation of monetary assets in the region is not due to agricultural activities for growing crops, and the implementation of the management function (Korolchuk et al., 2021) and high price characteristics of the land.

The calculation of activity concentration coefficients (formula 2) shows that the state indicator for 2018 is 0.2496 . This indicator is balanced and reflects the general situation with the spatial localization of indicators (Table 2). 
Table 2. Integral values and concentration coefficients of activity of financial and economic regulation of land use, 2018

\begin{tabular}{|l|l|l|l|l|}
\hline & $\begin{array}{l}\text { Integral } \\
\text { quantities }\end{array}$ & Kка & KкReg/Ukr & $\begin{array}{l}\text { The } \begin{array}{c}\text { place } \\
\text { rege } \\
\text { region }\end{array} \\
\text { in } \\
\text { Unking }\end{array}$ \\
\hline Vinnytsia region & - & $\mathbf{0 . 2 4 9 6}$ & - & - \\
\hline Volyn region & 1.2692 & $\mathbf{0 . 3 1 6 7}$ & +0.0672 & 7 \\
\hline Dnipropetrovsk region & 0.4952 & $\mathbf{0 . 1 2 3 6}$ & -0.1260 & 22 \\
\hline Donetskregion & 2.0344 & $\mathbf{0 . 5 0 7 7}$ & +0.2581 & 3 \\
\hline Zhytomyr region & 0.7668 & $\mathbf{0 . 1 9 1 4}$ & -0.0582 & 12 \\
\hline Transcarpatian region & 0.6954 & $\mathbf{0 . 1 7 3 5}$ & -0.0760 & 13 \\
\hline Zaporizhia region & 0.6682 & $\mathbf{0 . 1 6 6 8}$ & -0.0828 & 15 \\
\hline Ivano-Frankivsk region & 0.8947 & $\mathbf{0 . 2 2 3 3}$ & -0.0263 & 9 \\
\hline Kyiv region & 0.5890 & $\mathbf{0 . 1 4 7 0}$ & -0.1026 & 20 \\
\hline Kirovograd & 2.0667 & $\mathbf{0 . 5 1 5 8}$ & +0.2662 & 2 \\
\hline Lugansk region & 0.6323 & $\mathbf{0 . 1 5 7 8}$ & -0.0918 & 16 \\
\hline Lviv region & 0.3686 & $\mathbf{0 . 0 9 2 0}$ & -0.1576 & 25 \\
\hline Mykolaiv region & 1.5002 & $\mathbf{0 . 3 7 4 4}$ & +0.1248 & 6 \\
\hline Odessa region & 0.6264 & $\mathbf{0 . 1 5 6 3}$ & -0.0932 & 17 \\
\hline Poltava region & 1.7167 & $\mathbf{0 . 4 2 8 4}$ & +0.1788 & 4 \\
\hline Rivne region & 1.0890 & $\mathbf{0 . 2 7 1 8}$ & +0.0222 & 8 \\
\hline Sumy region & 0.4603 & $\mathbf{0 . 1 1 4 9}$ & -0.1347 & 23 \\
\hline Ternopil region & 0.6028 & $\mathbf{0 . 1 5 0 4}$ & -0.0991 & 18 \\
\hline Kharkiv region & 0.5697 & $\mathbf{0 . 1 4 2 2}$ & -0.1074 & 21 \\
\hline Kherson region & 1.5073 & $\mathbf{0 . 3 7 6 1}$ & +0.1266 & 5 \\
\hline Khmelnytsky region & 0.5993 & $\mathbf{0 . 1 4 9 6}$ & -0.1000 & 19 \\
\hline Cherkasy region & 0.7701 & $\mathbf{0 . 1 9 2 2}$ & -0.0574 & 11 \\
\hline Chernivtsi region & 0.8732 & $\mathbf{0 . 2 1 7 9}$ & -0.0317 & 10 \\
\hline Chernigov region & 0.3991 & $\mathbf{0 . 0 9 9 7}$ & -0.1500 & 24 \\
\hline Kyiv (city) & 0.6754 & $\mathbf{0 . 1 6 8 6}$ & -0.0810 & 14 \\
\hline & 3.1314 & $\mathbf{0 . 7 8 1 5}$ & +0.5319 & 1 \\
\hline & & & \\
\hline
\end{tabular}

The regions of the state are significantly differentiated according to this parameter. Only 8 regions exceed the national level. The indicators of other regions are lower. The Zaporizhia (0.2233) and the Cherkasy regions $(0.2179)$ are closer to the state level. Groups of regions were grouped to identify spatial features. Groups with possibilities of concentration (concentration) of activity of financial and economic regulation are allocated. The first group consists of regions with the maximum coefficients, which are determined by the highest priority in terms of regulatory activity. Similar features are characteristic of the formation of financial flows of these regions. Group II consists of regions of high concentration; III - average; IV - low. The parameters of the coefficients within the groups are investigated. The average values gradually decrease from the group I to group IV (Table 3). 
Table 3. Grouping of regions of Ukraine by the coefficient of concentration of activity in the field of land use

\begin{tabular}{|c|c|c|c|c|c|}
\hline \multirow[b]{2}{*}{ № } & \multirow[b]{2}{*}{ Region } & \multicolumn{3}{|c|}{$\begin{array}{l}\text { Parameters within the } \\
\text { group }\end{array}$} & \multirow[b]{2}{*}{ Characteristics of the group } \\
\hline & & $\min$. & $\max$. & aver. & \\
\hline I & $\begin{array}{c}\text { Kyiv (city), Kyiv, } \\
\text { Dnipropetrovsk, Odessa, } \\
\text { Kharkiv, Lviv, Vinnytsia regions }\end{array}$ & 0.3167 & 0.7815 & 0.5491 & $\begin{array}{l}\text { The group of the highest level of } \\
\text { concentration of activity, the regions of } \\
\text { which are determined by the highest } \\
\text { priority in terms of regulatory activity and } \\
\text { the formation of financial flows }\end{array}$ \\
\hline II & $\begin{array}{l}\text { Poltava, Zaporizhia, Cherkasy, } \\
\text { Khmelnytsky, Donetsk, } \\
\text { Zhytomyr region }\end{array}$ & 0.1735 & 0.2718 & 0.2226 & $\begin{array}{l}\text { A group of a high level of concentration, } \\
\text { the regions of which are determined by a } \\
\text { significant priority in terms of regulatory } \\
\text { activity and the formation of financial } \\
\text { flows }\end{array}$ \\
\hline III & $\begin{array}{l}\text { Chernihiv, Zakarpattia, } \\
\text { Kirovograd, Nikolaev, Sumy, } \\
\text { Kherson, Ivano-Frankivsk, } \\
\text { Ternopil regions }\end{array}$ & 0.1422 & 0.1686 & 0.1553 & $\begin{array}{l}\text { Group of medium level of concentration, } \\
\text { the regions of which are determined by a } \\
\text { significant priority in terms of regulatory } \\
\text { activity and the formation of financial } \\
\text { flows }\end{array}$ \\
\hline IV & $\begin{array}{l}\text { Volyn, Rivne, Chernivtsi, } \\
\text { Luhansk region }\end{array}$ & 0.0920 & 0.1236 & 0.1077 & $\begin{array}{l}\text { Low-concentration group, the regions of } \\
\text { which are determined by the lowest } \\
\text { priority in terms of regulatory activity and } \\
\text { the formation of financial flows }\end{array}$ \\
\hline
\end{tabular}

What do the levels of regulatory activity say for the incorporation of land resources into the market area of influence? Regions with high coefficients can more quickly integrate into the market area of influence (Fig. 4). Moreover, their quantitative parameters are more favorable for the development of interactions between land resources and the market. There are prerequisites for this and opportunities that are positioned in the system of contact points.

\begin{tabular}{|c|c|}
\hline Clusters & Specification \\
\hline $\begin{array}{c}\text { Regions of the } \\
\text { group I }\end{array}$ & $\begin{array}{l}\text { the highest level of concentration of activity provides the } \\
\text { preconditions for faster integration into the zone of market } \\
\text { influence. There are common points of contact between land and } \\
\text { business. Possibility of inclusion of land resources in the } \\
\text { activity of innovation and trust funds, exchange activity. }\end{array}$ \\
\hline $\begin{array}{l}\text { Regions of the } \\
\text { group II }\end{array}$ & $\begin{array}{l}\text { high level of concentration provides significant opportunities for } \\
\text { integration into the market environment. It is possible to identify } \\
\text { common points of contact. Promising are the investment } \\
\text { processes, the activities of management companies. }\end{array}$ \\
\hline $\begin{array}{l}\text { Regions of the } \\
\text { group III }\end{array}$ & $\begin{array}{l}\text { the average level of concentration provides opportunities for } \\
\text { integration and building interactions between land and business. } \\
\text { The activity of joint-stock companies, private banking is } \\
\text { possible. But to improve these processes, it is necessary to use } \\
\text { support measures and tools. }\end{array}$ \\
\hline $\begin{array}{l}\text { Regions of the } \\
\text { group IV }\end{array}$ & $\begin{array}{l}\text { A low level of concentration implies not high enough } \\
\text { opportunities for interactions. Support measures and tools are } \\
\text { needed to improve these processes. It may be appropriate to } \\
\text { develop niche interactions within individual communities. }\end{array}$ \\
\hline
\end{tabular}

Figure 4. Opportunities for the incorporation of land resources into the zone of market influence 
After passing the stage of incorporation, the natural resource enters the market environment. Entrepreneurial activity is an important prerequisite and factor for its implementation in this environment. The purpose of development is to position the natural resource in the market environment, expanding the boundaries of its operation. Besides, a list of new competencies will be gradually formed.

It is already possible to identify several examples of entrepreneurial activity for modern Ukraine. In particular, the activity of agricultural holdings is successful. For 2018, there are 85 agricultural holdings in the country and the leader in the land bank is Kernel. Land resources here serve as a basis for growing crops and industrial crops. Exchange activity in the field of land use is promising. Already, some agricultural holdings are listed on the Warsaw Stock Exchange.

With the introduction of the land market, it is possible to include land resources in banking. Land can be used for lending operations. Besides, land use consulting is promising.

Entrepreneurial activity is associated with the possibility of forming a market for natural resource assets, which means natural resources that are included in economic activity (circulation), can generate cash flows and form economic benefits (income) (Yankovyi et al., 2020). Applied features of a natural resource asset are that it: 1) provides the formation of possible economic benefits (income); 2) the entity may control the income for the use of the asset; 3) there is a legal act that provides the ability to generate and control income for the use of the asset. An important feature of a natural resource asset is the identified owner, manager, and user of the natural resource, which guarantees its profitability in the long run (Khvesyk, Bystryakov, Klynovoi, 2018; Bystriakov, 2018). An important tool (key) to the formation of the asset is an entrepreneurial activity.

Natural resources as an asset of a market economy. Further integration of the natural resource into the market environment reveals its new features and properties. With the development of entrepreneurial activity and the establishment of the market of natural resource assets, the resource gradually forms the features of the market economy asset. It is important to note that the natural resource asset retained the natural resource base (origin), although, with the strengthening of market positions, the natural resource as an asset of a market economy makes a "separation" from these positions. The study of this experience is useful to understand possible changes in the properties of natural resources and their participation in economic activities. The participation of natural resources in the activities of investment funds, exchanges can lead to the formation of these formations (Koval, Prymush, Popova, 2017; Koval, Slobodianiuk, Yankovyi, 2018).

Given the manifestation of these processes, this will be an impetus for a new level of development and natural resources and markets. Moreover, it will contribute to the formation of a platform that provides for different variations of interactions with natural resources (including innovation).

Important processes that accompany the movement to an economic asset are the strengthening of cash flow generation, the formation of profits, which can lead to an increase in value. Under these conditions, the processes of corporatization and capitalization of natural resources become relevant.

Assessment of the potential of the formations "natural resource as an asset of the market economy" revealed that such phenomena are quite complex (in particular, for the conditions of modern Ukraine). It is logical to assume that significant institutional upheavals and preconditions are important for such processes (Bublyk, Koval, Redkva, 2017). Provided that there will be a stage of transition from a natural resource asset to an economic asset, then, with the low development of institutions, the preconditions for this will simply not be formed.

Provided that such formations of natural resources appear, the question of the "place" of their functioning, the disclosure of potential and arises. A similar place may be the platform market. We can say that the 
platform market is an institutional basis for unlocking the potential of various forms of natural resources.

A platform market is a specific environment with the necessary infrastructure for improved interaction between different actors (including natural resources and business) to realize common values (Kvach, Piatka, Koval, 2020). The purpose of platform markets, in terms of revealing new properties of natural resources and their integration into the zone of market influence, is the formation of conditions and opportunities for interactions of a new level with the participation of natural resources. The platform market operates taking into account not only the technical component but also others. In particular, platforms (for example, exchanges) worked for the industrial era in the absence of modern information technologies. The platform is not only in the modern sense, but there were examples from the past, there the basis was different. Today the basis is mostly informational.

\section{Conclusions}

The study showed that to incorporate a natural resource into the area of market influence, it needs to go through several stages, and each of them is characterized by changes in the properties of resources, their gradual interaction with market participants.
Even though there is a rather low level of capitalization of natural resources (in particular for land $-12.0 \%$, water $-10.8 \%$ ), the coefficient of concentration of activity can identify some regions with good opportunities for incorporation. The regions of the state are significantly differentiated according to this concentration.

To improve the situation in the field of incorporation of natural resources into the zone of market influence, the state needs to create conditions and opportunities for these processes. Possibilities of institutional support of the processes of incorporation of natural resources into the zone of market influence are also connected with the issues of state support.

It is important to implement integrated management tools to coordinate natural resources within all relevant sectors, policies and institutions to achieve a common goal. The system of such management requires the parallel consideration of different uses of resources (as a natural resource and as an asset of a market economy) and provides a structure in which competing stakeholders can develop measures to address future problems and uncertainties. Besides, an important feature of management is the ability to manage not only one resource, but also related resources (land, water).

\section{References}

Bublyk, M., Koval, V., \& Redkva, O. (2017). Analysis impact of the structural competition preconditions for ensuring economic security of the machine building complex. Marketing and Management of Innovations, (4), 229240. doi: $10.21272 / \mathrm{mmi} .2017 .4-20$

Burkynskyi, B., Martienko, A., Khumarova, N., \& Prokopiuk, A. (2018). Property management dominants for recreational natural resources. Economics, Ecology, Socium, 2(4), 77-90. https://doi.org/10.31520/2616-7107/2018.2.48

Bystriakov, I.K. (2018). Spatial concept of substantiation of ecological and economic functioning. Economy of Ukraine, 11-12, 136-147. https://doi.org/10.15407/economyukr.2018.11.136

Doing Business (2020). Comparing BusinessRegulation in190 Economies. https://www.doingbusiness.org/

Global Innovation Index (2020). The Global Innovation Index 2020: Who Will Finance Innovation? https://www.wipo.int/edocs/pubdocs/en/wipo_pub_gii_2020.pdf

Global Water Partnership (2005). Integrated water resources management plans. Cap-Net. IWRM plans, Training module. 
Global Water Partnership (2012). Integrated Water Resources Management Guide. International Network of Basin Organizations (INBO) and the Global Water Partnership (GWP).

Khvesyk, M.A. (2020). Financial and economic principles of nature management regulation. DU IEPSR NAN Ukrainy, Kyiv.

Khvesyk, M.A., Bistryakov, I.K., Klynovoi, D.V. (2018). The economic mechanism of the reconstructive functioning of Ukraine in the natural resources management system. Economy of Ukraine, 3, 3-20. https://doi.org/10.15407/economyukr.2018.03.003

Khvesyk, M.A., Lyzun S.O. (2015). Economic aspects of natural resources management in the context of decentralization of power in Ukraine. DU IEPSR NAN Ukrainy, Kyiv

Korolchuk, M., Korolchuk, V., Myronets, S., Boltivets, S., Mostova, I., \& Koval, V. (2021). Competitive Properties of Trading Companies Managers. Revista Geintec-Gestao Inovacao e Tecnologias, 11(2), 941-954.

Kostetska, K., Smol, M., \& Gaska, K. (2018). Rational nature use of recreational management subjects on the basis of inclusive. Economics, Ecology, Socium, 2(4), 31-40. https://doi.org/10.31520/2616-7107/2018.2.4-4

Koval, V., Prymush, Y., \& Popova, V. (2017). The influence of the enterprise life cycle on the efficiency of investment. Baltic Journal of Economic Studies, 3(5), 183-187. doi:10.30525/2256-0742/2017-3-5-183-187

Koval, V., Slobodianiuk, O., \& Yankovyi, V. (2018). Production forecasting and evaluation of investments using Allen two-factor production function. Baltic Journal of Economic Studies, 4(1), 219-226. doi:10.30525/22560742/2018-4-1-219-226

Kvach, Y., Piatka, N., \& Koval, V. (2020). Management of sustainable entrepreneurship adaptation to tax changes in environmental investment. Baltic Journal of Economic Studies, 6(5), 96-105. https://doi.org/10.30525/22560742/2020-6-5-96-105

Maliuha, N.M., Zamula I.V. (2010). Natural capital: identification. Visnyk ekonomichnoi nauky Ukrainy, 1, 6771.

Ministry of Agriculture of Ukraine (2020). Investment projects. https://agro.me.gov.ua

Pimonenko, T., Prokopenko, O., \& Dado, J. (2017). Net zero house: EU experience in Ukrainian conditions. International Journal of Ecological Economics and Statistics, 38(4), 46-57.

Prokopenko, O.V., \& Shkola, V.Y. (2012). Controlling of the ecological and economic enterprise security on the bases of ecomarketing. Marketing and Management of Innovation, 4, 337-346.

Pyrozhkov, S.I., Khvesyk, M.A. (2015). Economic assessment of natural resources of Ukraine. DU IEPSR NAN Ukrainy, Kyiv.

Rudenko, V.P. (1993). Geography of natural resource potential of Ukraine. Academy, Kyiv.

Stepanenko, A. V., Herasymov, M. I. (2002). Economic security of Ukraine. Rehionalna ekonomika, 2, 39-54.

Sunduk A.M. (2020). Possibilities of integration of natural resources into the zone of market influence. Kherson.

Tamosiuniene, R., Demianchuk, M., Koval, V. (2019). State Regulation of Bankruptcy Relations in the National Economy. Economics. Ecology. Socium, 3 (4), 19-27.

Yankovyi O., Koval V., Trokhymets O., Karpenko M., Matskevich Y. (2020). Economic assessment of investment on the basis of production functions. Turismo: Estudos \&Práticas, 2. 